University of Wyoming College of Law

Law Archive of Wyoming Scholarship

$5-22-2018$

\title{
Roman Law Scholarship and Translation in Early Twentieth- Century America
}

Timothy G. Kearley

University of Wyoming College of Law, tkearley@uwyo.edu

Follow this and additional works at: https://scholarship.law.uwyo.edu/other

\section{Recommended Citation}

Kearley, Timothy G., "Roman Law Scholarship and Translation in Early Twentieth-Century America" (2018). Other Publications and Activities. 9.

https://scholarship.law.uwyo.edu/other/9

This Article is brought to you for free and open access by the UW College of Law Faculty Scholarship at Law Archive of Wyoming Scholarship. It has been accepted for inclusion in Other Publications and Activities by an authorized administrator of Law Archive of Wyoming Scholarship. 


\section{Roman Law Scholarship and Translation in Early Twentieth Century America Timothy G. Kearley}

Over a decade ago, I wrote of how Friedrich Heinrich Blume, a German immigrant who became a Wyoming Supreme Court justice in 1920, single-handedly translated Justinian's Code and Novels into English. ${ }^{1}$ The justice eventually produced a 4,500-plus page annotated version of these ancient laws. Although Blume's Annotated Justinian Code never was printed, I edited and retyped the manuscript and published it online ${ }^{2}$ more than forty years after his death.

However, my ongoing research revealed other interesting, related, stories, all of which deserved to be told. The recent publication of The Codex of Justinian ${ }^{3}$ is the impetus for relating them in my new book Lost in Translations. The Codex of Justinian is a new English translation of the Code by an Anglo-American panel that based its collective work upon Justice Blume's "lone-wolf" effort. I hope the new translation finally will bring Blume the attention he long has merited. However, the other stories I referred to above also are worthy of being written, and their protagonists deserve attention as well.

In continuing to study Blume's involvement with Roman law, I discovered other Roman law scholars and translators of his era who are little known today: Samuel Parsons Scott (1846-1929) and Clyde Pharr (1883-1972), both of whom

\footnotetext{
- University of Wyoming, College of Law

1 Timothy G. Kearley, Justice Fred Blume and the Translation of Justinian's Code 99 LAW LIBR. J. 525 (2007).

2 http://www.uwyo.edu/lawlib/blume-justinian (last viewed April 26, 2017).

3 The Codex of Justinian: A New Annotated Translation, with Parallel Latin and Greek Text, Based on a Translation by Justice Fred H. Blume (Bruce W. Frier ed., 2016).
} 
created massive translations of ancient Roman law; Charles Phineas Sherman (1874-1962), a lawyer-professor who translated some Roman law and wrote prolifically about it; and, finally, Charles Sumner Lobingier (1866-1956), a judgeprofessor who wrote much about Roman law, translated a little, championed the publication of Scott's work, and was connected to all of the others. All of these men were prominent during their lifetimes but are largely forgotten now.

Although Scott was some thirty years older than Blume, the others were roughly part of the same cohort. Blume, Lobingier, and Sherman all attended college or university between 1884-1898, during the Gilded Age, with Pharr attending slightly later, in the first decade of the 1900s. Why, I wondered, did these intelligent, energetic men devote so many years of their lives in the twentieth century to studying and writing about ancient Roman law? And what equipped them for such a demanding endeavor?

The answers I found make up the threads of my narrative in Lost in Translations. ${ }^{4}$ They include the histories of American culture and educationincluding legal education-whose institutions were undergoing great changes during the Gilded Age and on into the first few decades of the twentieth century. The answers also involve descriptions of the legal profession, the function and uses of Roman law during that time, the Restatement of the Law movement, and the Riccobono Seminar on Roman Law in America, the last of which brought together many of the leading American Romanists of the era. I have not tried to survey all

\footnotetext{
4 Timothy G. Kearley, Lost in Translations: Roman LaW Scholarship and Translation in Twentieth-Century America (Durham, N.C.: Carolina Academic Press, 2018).
} 
Roman law translation and scholarship of the era but have focused instead on the five scholars noted above as being good representatives of the class.

I have told some of these stories previously in academic journals, ${ }^{5}$ but not as completely, or in the integrated way I present them in this book. Moreover, some of the tales have hardly been told at all. In particular, almost nothing has been written of Charles Sumner Lobingier, and little about Charles Phineas Sherman (aside from his autobiography, ${ }^{6}$ which offers a highly selective perspective). Clyde Pharr was the subject of a recent article, but I have more to add of him, too. ${ }^{7}$ Also, after further research and consideration, I have added information about, and changed my opinion on, some the subjects I wrote of before. For example, I have included here a significant amount of relevant and highly interesting information I discovered in the correspondence of Roscoe Pound. Pound's connection to Lobingier, Sherman, and the Riccobono Seminar seem not to have been written of previously. In fact, much of the information I share in the book is archival and therefore has not widely available or discussed. I also have gone into much more detail here than in my previous writings about the history of American education as it relates to the classical past.

My thesis is that, to a significant extent, the Roman law translation and scholarship of the men whose stories I tell was motivated and supported by their

\footnotetext{
${ }^{5}$ In addition to the history of Blume's translation work cited in note 2 above, they are: Timothy G. Kearley, The Enigma of Samuel Parsons Scott, 10 RoMAN LEGAL Tradition 1 (2014); \& Timothy G. Kearley, From Rome to the Restatement: S.P. Scott, Fred Blume, Clyde Pharr, and Roman Law in Early Twentieth Century America, 108 LAW LIBR. J. 55 (2016).

${ }^{6}$ Charles Phineas Sherman, Academic Adventures : A LaW School Professor's RECOLLECTIONS AND OBSERVATIONS (1944).

${ }^{7}$ See Linda Jones Hall, Clyde Pharr, the Women of Vanderbilt, and the Wyoming Judge: The Story Behind the Translation of the Theodosian Code in Mid-Century America 8 Roman LEGal TRAdition 1 (2012).
} 
classically-oriented educations and, more generally, by a pervasive American cultural connection to the classical past that we find hard to imagine today. Although each of the scholars whose stories I tell had personal motives for his work - the principle one being to create an historical legacy—each of them also felt connected to the Roman legal tradition in a way the modern American lawyer would find puzzling. Many of the best known American lawyers and legal scholars of the first half of the twentieth century had classically-oriented educations and were knowledgeable about, or at least sympathetic to, Roman law. Roscoe Pound is an excellent example; while known mainly for being a long-time dean of the Harvard Law School and as a legal philosopher, Pound also was a Roman law scholar. Given this milieu, it seemed perfectly reasonable and desirable to Scott, Blume, et al. to devote much of their lives to translating or explicating that ancient law. ${ }^{8}$

In addition to offering a narrative about these men and their milieu, I hope to facilitate the reader's own exploration of the field. To that end, I include in the book appendices listing all of the writings of the main characters, along with reviews of those writings, and a selective bibliography of the sources I found most useful in my investigations.

The classical past continues to be relevant to the modern world. The popularity of writings by classicists such as Mary Beard ${ }^{9}$ and of movies and

\footnotetext{
${ }^{8}$ It is worth noting that devotion to Roman law also seems to operate as something of an elixir and anti-aging medicine. Our subjects worked productively past the typical age of retirement and enjoyed an average life-span of nearly 90 years. Justice Blume lived to be 96 years of age.

${ }^{9}$ See, for example, Mary Beard, Grenfell Tower and the Fire of Rome, MARY BEARD's BLOG (July 22, 2017), https://www.goodreads.com/author_blog_posts/15460197-
} 
television series on ancient history (such as Rome, Troy, Empire, etc.) demonstrate that there remains a significant interest in the ancients. The classics are being used in social media and popular magazines to discuss subjects of great current concern, and to consider how the ancients confronted many of the same fundamental problems we face at present. ${ }^{10}$ I hope Lost in Translations will provide yet another point of entry into the classical past.

grenfell-tower-and-the-fire-of-rome. Beard also has written several best-selling books on ancient history.

${ }^{10}$ See, for example, Sara L. Hales, Blog: Teaching Classics in the Age of \#MeToo, SCS BLOG (Feb. 14, 2018), https://classicalstudies.org/scs-blog/sara-l-hales/blogteaching-classics-age-metoo, and Michael Crowley, Why the White House is Reading Greek History, Politico Magazine (June 21, 2017), https://www.politico.com/magazine/story/2017/06/21/why-the-white-house-isreading-greek-history-215287. 